\title{
An Overlooked Construction Manual for the Quadrans Vetustissimus
}

One of the red threads running through the history of pre-modern Islamic and European horology is the continuing use of an approximate formula for finding the time of the day from the altitude of the Sun, the origins of which appear to lie in ancient India. ${ }^{1}$ Following David A. King, it may be written as $\mathrm{T}=1 / 15 \operatorname{arc} \sin (\sin \mathrm{h} / \sin \mathrm{H})$, where $\mathrm{H}$ is the Sun's meridian altitude on a given day, $\mathrm{h}$ is its instantaneous altitude, and $\mathrm{T}$ is the corresponding time in seasonal hours since sunrise (before noon) or before sunset (after noon). ${ }^{2}$ The formula relating these three parameters to each other has the virtue of being applicable to any latitude, although the results will be considerably less accurate for northern latitudes than they are for climates closer to the equator. At $48^{\circ}$, the maximum error, which is reached at the summer solstice, can exceed a quarter of an equinoctial hour. ${ }^{3}$ Knowledge of the formula or its limitations was not strictly required, however, to make us of its practical embodiments, which included the universal horary quadrant. Medieval Latin manuscripts typically represent this instrument in the form classified as quadrans vetus, which is characterized by the following three elements: (i) a diagram of curved lines for finding unequal hours; (ii) a shadow square used for the purposes of altimetry, planimetry, and stereometry; ${ }^{4}$ and (iii) a movable cursor

\footnotetext{
${ }^{1}$ David A. King, In Synchrony with the Heavens: Studies in Astronomical Timekeeping and Instrumentation in Medieval Islamic Civilization, 2 vols., Vol. 2: Instruments of Mass Calculation (Leiden: Brill, 2005), pp. 111196.

${ }^{2}$ Ibid., pp. 125-128.

${ }^{3}$ Ibid., pp. 131-132; Margarida Archinard, “The Diagram of Unequal Hours,” Annals of Science, 1990, 47:173190, p. 185.

${ }^{4}$ On shadow squares, see King, In Synchrony (cit. note 1), pp. 247-252. On their use in conjunction with the quadrant, see Annalisa Simi, "Celerimensura e strumenti in manoscritti dei secoli XIII-XIV," in Itinera mathematica: studi in onore di Gino Arrighi per il suo $90^{\circ}$ compleanno, edited by Raffaella Franci, Paolo Pagli,
} 
showing the degrees of the zodiac and dates of the Julian calendar. The inclusion of the cursor, although not essential to the functionality of the instrument, allowed users to infer parameter $\mathrm{H}$ from the current date without recourse to computational tables (and do so at any latitude).

While its Islamic origins are not in doubt, ${ }^{5}$ the chronology and circumstances under which the universal horary quadrant entered Christian Europe are yet to be fully understood. One complicating factor is that the horary quadrants described or depicted in Latin manuscripts of the eleventh and twelfth centuries differ significantly from the quadrans vetus first attested in texts dating to the thirteenth century. ${ }^{6}$ In the earlier descriptions, there is no hint of a shadow square and the familiar diagram of curved hour-lines is absent, too. In its

and Laura Toti Rigatelli (Siena: Centro studi sulla matematica medioevale, Università di Siena, 1996), pp. 71121, at pp. 82-91.

${ }^{5}$ The three features characterizing the quadrans vetus are already attested in an Arabic text on the use of the quadrant that King has argued was written in Baghdad in the ninth or tenth century. See David A. King, "A Vetustissimus Arabic Treatise on the Quadrans Vetus," Journal for the History of Astronomy, 2002, 33:237255. On Islamic quadrants more generally, see King, In Synchrony (cit. note 1), pp. 71-80, 162-239; Peter Schmalzl, Zur Geschichte des Quadranten bei den Arabern (Munich: Salesianische Offizin, 1929).

${ }^{6}$ Paul Tannery, "Le Traité du quadrant de Maître Robert Anglès (Montpellier, XIII ${ }^{\mathrm{e}}$ siècle): texte latin et ancienne traduction grecque," Notices et extraits des manuscrits de la Bibliothèque Nationale et autres bibliothèques, 1897, 35.2:561-640; Nan L. Hahn, Medieval Mensuration: Quadrans Vetus and Geometrie Due Sunt Partes Principales... (Philadelphia, PA: American Philosophical Society, 1982); Wilbur R. Knorr, “Sacrobosco's Quadrans: Date and Sources,” Journal for the History of Astronomy, 1997, 28:187-222; Knorr, “The Latin Sources of Quadrans Vetus, and What They Imply for Its Authorship and Date," in Texts and Contexts in Ancient and Medieval Science, edited by Edith Sylla and Michael McVaugh (Leiden: Brill, 1997), pp. 23-67. For an extended version of the latter article, see Knorr, “The Latin Sources of 'Quadrans vetus': 'Humeniz', Sacrobosco, Campanus et al.," unpublished typescript in Stanford University Libraries, Department of Special Collections, Wilbur Knorr Papers, SC 933, Box 1. 
place, the quadrant has a set of straight lines drawn in parallel to one of the bases, giving it the appearance of a sine quadrant. ${ }^{7}$ The difference between the two Latin types was first highlighted by Josep Maria Millàs i Vallicrosa in a groundbreaking article published in 1932, in which he introduced the label quadrans vetustissimus to refer to the earlier version. ${ }^{8}$ As with the planispheric astrolabe, it is likely that the vetustissimus quadrant entered Christian Europe via Catalonia, where it presumably first arrived in the late tenth or early eleventh century. 9

No medieval specimen of the quadrans vetustissimus has come down to us and the known written testimonies regarding the instrument are few and frustratingly terse. On the pictorial side of things, our most useful early witnesses are two nearly identical drawings found in MSS Paris, Bibliothèque nationale de France, lat. 7412, fol. 16v (s. XI; see Fig. 1), and Vatican City, Biblioteca Apostolica Vaticana (henceforth: BAV), Reg. lat. 1661, fol. 86v $\left(\mathrm{s} . \mathrm{XI}^{\mathrm{ex}}\right) .{ }^{10}$ They give us a relatively clear indication that the front plate was meant to be

\footnotetext{
${ }^{7}$ Richard Lorch, "Some Early Applications of the Sine Quadrant,” Suhayl, 2000, 1:251-272; King, In Synchrony (cit. note 1), pp. 71-74, 173.

${ }^{8}$ J. Millàs Vallicrosa, "La introducción del cuadrante con cursor en Europa,” Isis, 1932, 17:218-258. For some supplementary remarks, see Ernst Zinner, Entstehung und Ausbreitung der Copernicanischen Lehre, 2nd ed. (Munich: Beck, 1988 [1st ed. Erlangen, 1943]), pp. 66-67, 498-499; Zinner, Deutsche und niederländische astronomische Instrumente des 11.-18. Jahrhunderts (Munich: Beck, 1956), pp. 154-156.

${ }^{9}$ On Catalonia's role as a scientific contact zone in the late tenth century, see the literature cited in note 28 below. The same route of transmission might account for the eleventh-century text on a latitude-specific quadrant discussed in Catherine Jacquemard, Olivier Desbordes, and Alain Hairie, "Du quadrant vetustior à l'horologium viatorum d'Hermann de Reichenau: étude du manuscrit Vaticano BAV Ott. lat. 1631, f. 16-17v," Kentron, 2007, 23:79-125.

${ }^{10}$ The Vatican drawing was already discussed by Millàs Vallicrosa, "La introducción” (cit. note 8), p. 234 and pl. 13. See also the digital reproduction available at https://digi.vatlib.it/view/MSS_Reg.lat.1661 (accessed 5 June 2019). For the Paris manuscript, see Arianna Borrelli, Aspects of the Astrolabe: 'architectonica ratio' in
} 
equipped with a set of parallel lines running downward from the base holding the instrument's two sighting vanes and ending at the graduated hour-scale that lines the inner limb or quarter-circle. In the Vatican MS, the number of lines shown suggests that there was supposed to be one line for each of the 90 degrees of the inner and outer limbs. The Paris MS, by contrast, only has 55 such lines.

In between the two limbs lies the sliding track for the movable cursor, which in both manuscripts is depicted as featuring the names of the Julian months in two rows parallel to the limb, with the solstitial months of December and June located at the far edges and running across the two rows. The equinoxes are indicated to lie exactly in the middle of March and September, which agrees well with the astronomical situation in the mid-eleventh century, besides being supported by the widely circulated treatise De utilitatibus astrolabii. ${ }^{11}$ A segmented curved line that runs through the middle of the cursor gives us some idea of its operative dimensions. Although both renditions of this line are rather crude for lack of symmetry, the Vatican one does take up something close to the $48^{\circ}$ of the outer limb that one would expect based on a rounded value for the obliquity of the ecliptic of $24^{\circ}$. It is also clear from looking at the drawings that the portions of this line assigned to each pair of Julian months were not equally sized, but were supposed to become increasingly narrow as one moved from the centre towards the solstices. A subtle addition to each sketch is the

Tenth- and Eleventh-Century Europe (Stuttgart: Steiner, 2008), pp. 195-196, 242-243, and the description by Emmanuel Poulle in Lumières de l'an mil en Orléanais: autour de millénaire d'Abbon de Fleury (Turnhout: Brepols, 2004), pp. 231-232.

${ }^{11}$ See De utilitatibus astrolabii, c. 3, ed. Nicolai Bubnov, Gerberti Opera Mathematica (972-1003) (Berlin: Friedländer \& Sohn, 1899), pp. 124-127. For the relevant context, see C. Philipp E. Nothaft, “Bede’s horologium: Observational Astronomy and the Problem of the Equinoxes in Early Medieval Europe (c.7001100)," English Historical Review, 2015, 130:1079-1101; Nothaft, Walcher of Malvern: De lunationibus and De Dracone; Study, Edition, Translation, and Commentary (Turnhout: Brepols, 2017), pp. 251-261. 
instrument's plumb line, which appears in two different positions representing the extreme cases of $0^{\circ}$ and $90^{\circ}$ solar altitude. The two representations also share an obvious flaw in that the degree scale from $0^{\circ}$ to $90^{\circ}$ at the outer limb runs in the wrong direction-opposite to what is indicated by the solstices on the cursor and the hour markings at the inner limb, as well as by the location of the two sighting vanes.

<Fig. 1 here>

In both manuscripts, the drawn quadrant accompanies a text with the incipit Componitur horologium, which gives a very concise explanation of how to use such an instrument to measure the time of the day. ${ }^{12}$ One detail mentioned in this text that is not already obvious from looking at the accompanying drawing is that the instrument's plumb line is equipped with a

\footnotetext{
12 This is text VIIa in J. Millàs Vallicrosa, Assaig d'història de les idees fisiques i matemàtiques a la Catalunya medieval, vol. 1 (Barcelona: Institució Patxot, 1931), pp. 304-305. Other copies I have seen include: Avranches, Bibliothèque Municipale, 235, fol. 67v (s. XII); Barcelona, Archivo de la Corona de Aragón, Ripoll 225, fol. 21r-v (s. XI); Copenhagen, Det Kongelige Bibliotek, GKS $2772^{\circ}$, fol. 32va (s. XIII); Düsseldorf, Universitätsund Landesbibliothek, F 13, fol. 62r-v (s. XVI); Erfurt, Universitäts- und Forschungsbibliothek, Dep. Erf. CA $4^{\circ} 351$, fol. 31r (s. XIII); Leiden, Universiteitsbliotheek, Scaliger 38, fol. 45v (s. XI); London, British Library, Add. 17808, fol. 79v (s. XI); Luxembourg, Bibliothèque nationale, I.27, fol. 154v (s. XII); Munich, Bayerische Staatsbibliothek, Clm 14763, fol. 203v (s. XII); Oxford, Bodleian Library, Auct. F.3.14, fols. 156v-157r (s. XII); Oxford, Bodleian Library, Rawlinson G.40, fol. 30r (s. XII); Oxford, Corpus Christi College, 283, fols. 89r, 95r-v (s. XI); Vatican City, BAV, lat. 3101, fol. 7r (s. XII); Vatican City, BAV, lat. 4539, fols. 130v-131r (s. XV/XVI); Vatican City, BAV, Pal. lat. 1356, fols. 107v-108r (s. XII); Vatican City, BAV, Pal. lat. 1377, fol. 106v (s. XI/XII); Vatican City, BAV, Reg. lat. 598, fol. 119r (s. XI); Vatican City, BAV, Reg. lat. 1661, fol. 86r (s. XI ${ }^{\mathrm{ex}}$ ); Zurich, Zentralbibliothek, Car. C 172, fols. 80v-81v (s. XI). The Barcelona manuscript is transcribed in Gemma Puigvert i Planagumà, Astronomia i astrologia al monestir de Ripoll (Bellaterra: Universitat Autònoma de Barcelona, 2000), p. 144. Another copy, which I have not been able to check, appears in MS Kassel, Universitätsbibliothek, $8^{\circ}$ astron. 4, fols. 69v-70r (s. XVI). I am very grateful to David Juste for his helpful pointers to this and several other manuscripts listed here.
} 
parvissimum curriculum - a sliding bead that can be moved to mark points on the hour-line plate. This mobile marker also receives a mention (as parvum medicurriculum) in a similar text starting Si diei horas scire desideras, which accompanies a coarse drawing of the quadrant in MS London, British Library, Royal 15.B.IX, fol. 70v (s. XII/XIII). ${ }^{13}$ Yet another source mentioning the parvissimum curriculum is attested in the famous MS Barcelona, Archivo de la Corona de Aragón, Ripoll 225, fols. 35r-38r (s. XI). This text with the incipit In curriculo XII menses is much longer than the two already mentioned and offers some additional details concerning the instrument, which is here said to be equipped with a shadow scale divided into 60 'points' and 50 parallel lines for measuring the hour. ${ }^{14}$

To date, only one written source on the quadrans vetustissimus has been known to provide any information on how the cursor was supposed to be constructed. This text, starting Circuli quadram, is transmitted in numerous twelfth-century manuscripts as a fellow-traveller of the treatise De horologio viatorum, ${ }^{15}$ long attributed to Hermann of Reichenau (d. 1054),

\footnotetext{
${ }^{13}$ Other twelfth-century witnesses include: Oxford, Jesus College, 4, fol. 92v; Salzburg, Erzabtei St. Peter, Stiftsbibliothek, a V 7, fol. 110r; Wrocław, Biblioteka Uniwersytecka, R 55, fol. 75r-v. For a transcription, see the apparatus to text VIIa in Millàs Vallicrosa, Assaig (cit. note 12), p. 305. The transmission of this text and the briefer Componitur horologum has yet to be fully elucidated. See Millàs Vallicrosa, "La introducción” (cit. note 8), pp. 220-228; Catherine Jacquemard, "Recherches sur la composition et la transmission de la Geometria incerti auctoris: à propos du De profunditate maris vel fluminis probanda, Avrances, BM 235, f. 36," in Science antique, Science médiévale (Autour d'Avranches 235), edited by Louis Callebat and Olivier Desbordes (Hildesheim: Olms, 2000), pp. 81-119, at pp. 84, 93-95, 107.

14 The text is reproduced in Millàs Vallicrosa, Assaig (cit. note 12), pp. 305-307; Puigvert i Planagumà, Astronomia (cit. note 12), pp. 152-153. Its final lines also appear in MS Vatican City, BAV, Reg. lat. 598, fol. 121r (s. XI), a reference I owe to David Juste. For discussion, see Millàs Vallicrosa, "La introducción” (cit. note 8), pp. 228-230, 236-239.

15 The text was printed by Bernhard Pez, Thesaurus anecdotorum novissimus, 6 vols., Vol. 3.2 (Augsburg: Veith, 1721-1729), cols. 136-138 (repr. in Patrologia Latina 143, cols. 409-410), on the basis of MS Salzburg,
} 
but now considered to be the work of his contemporary Berengarius. ${ }^{16}$ In contrast to In curriculo XII menses, which gives the number of parallel lines on the instrument as 50, the quadrant described in Circuli quadram operates with just 30 such lines. Its cursor has the familiar division into two rows for the names of the Julian months, but deviates from what we see in the drawings by placing the first four of the six line segments allocated to June in the outer row and the final two segments in the inner row (vice versa for December), thereby indicating that the summer solstice occurs not in the middle, but two thirds into the month. ${ }^{17}$ This was obviously done in order to conform to a still-widespread doctrine of the early medieval computus, according to which the solstices and equinoxes are all due to occur on

Erzabtei St. Peter, Stiftsbibliothsk, a v 7 (s. XII). For discussion, see Millàs Vallicrosa, "La introduccion” (cit. note 8), pp. 231-233. I have consulted the following twelfth-century manuscripts: Avranches, Bibliothèque Municipale, 235, fol. 75r-v; Göttingen, Niedersächsische Staats- und Universitätsbibliothek, philos. 42, fol. 12r-v; London, British Library, Royal 15.B.IX, fol. 60r-v; London, British Library, Egerton 823, fols. 30v-32v; Munich, Bayerische Staatsbibliothek, Clm 13021, fols. 80vb-81ra; Vatican City, BAV, Chigi F.IV.48, fols. 31v-32v. An incomplete thirteenth-century copy appears in MS Copenhagen, Det Kongelige Bibliotek, GKS $2772^{\circ}$, fol. 76ra.

${ }^{16}$ Jacquemard, Desbordes, and Hairie, "Du quadrant vetustior" (cit. note 9); David Juste, "Hermann der Lahme und das Astrolab im Spiegel der neuesten Forschung," in Hermann der Lahme: Reichenauer Mönch und Universalgelehrter des 11. Jahrhunderts, edited by Felix Heinzer and Thomas Zotz (Stuttgart: Kohlhammer, 2016), pp. 273-284, at pp. 278-282.

${ }^{17}$ MS Göttingen, Niedersächsische Staats- und Universitätsbibliothek, philos. 42, fol. 12v: “Mensium vero discretio sic fiat: in parte dextera duobus relictis spaciolis Ianuario VI, Februario VI, Martio VI, Aprili VI, Maio VI concedantur, Iunio IIII ante solstitium. Et hoc in superiori circulo. In inferiori vero circulo due post solsticium particule dentur Iunio. Iulio autem VI, Augusto VI, Septembri VI, Octobri VI, Novembri VI, Decembri IIII ante solstitium. Et hoc est in inferiori circulo. Post solsticium autem in superiore mensium circulo due particule que restant Decembri tribuantur. Deinde autem, ut supra dixi, Ianuario VI.” Most other witnesses and the text edited by Pez (n. 15) give only five spatiolae to February, but this can hardly have been the original intention, given the constraints of symmetry. 
the $12^{\text {th }}$ day before the Kalends of their respective month (i.e., 21 March, 20 June, 20 September, and 21 December). ${ }^{18}$

The other salient feature of the cursor described in Circuli quadram is that the space allotted to each month is not completely equal. Readers are told to divide each half of the cursor's middle line into five equal segments. The three segments closest to the equinox (located at the centre) will each be divided further into three smaller segments, whereas the two outer segments will share nine sub-divisions. ${ }^{19}$ This results in a total of 36 smaller segments (18 on each side of the equinox), of which each month will receive six. However, the 18 segments on the inside (covering March/September and one half each of April/August and February/October) will necessarily be $50 \%$ larger than those at the outsides (covering the other half of April/August and February/October and all of May/July, January/November, June and December). It goes without saying that this is a rather crude way of designing the cursor, although perhaps not quite as crude as previously assumed by Wilbur Knorr, who concluded from the text that there is "no firm precedent for an understanding of the calibration of the cursor before the thirteenth century." 20

If Circuli quadram is enough to call Knorr's verdict into question, it is refuted entirely by the existence of a previously unnoticed set of instructions on how to build a

\footnotetext{
${ }^{18}$ See on this background Nothaft, "Bede's horologium” (cit. note 11), pp. 1082-1095.

${ }^{19}$ MS Göttingen, Niedersächsische Staats- und Universitätsbibliothek, philos. 42, fol. 12v: “Tunc ab ipsa equinoctiali linea cursor in $\mathrm{V}$ dividatur in parte sinistra, quarum III $^{\mathrm{es}}$ que proxime sunt equinoctiali linee in III $^{\mathrm{a}}$ dividantur, unaqueque scilicet, et in VIIII due relique. Similiter faciendum est in dextera parte. Et notentur illa spaciola." The text edited by Pez (cit. note 15) states that each of the three divisions closest to the equinoctial line is to be divided further into four, but a reading of 'three' (III or $\left.I I I^{a}\right)$ is supported by most of the manuscripts.

${ }^{20}$ Knorr, "Sacrobosco's Quadrans" (cit. note 6), p. 213. Knorr erroneously read the text to mean that the six units assigned to each month (except February) are equal in size.
} 
quadrant of the vetustissimus type in MS Oxford, Bodleian Library, Auct. F.1.9, which was written at Worcester Cathedral Priory in the first half of the twelfth century, most likely between 1126 and $1140 .{ }^{21}$ The manuscript itself is well known for featuring a collection of then-recent computistical, mathematical, and astronomical material, including the earliest surviving copy of Adelard of Bath's translation of the astronomical tables of al-Khwārizmī (on fols. $99 \mathrm{v}-159 \mathrm{v}$ ). No attention has been paid, however, to the extended section on astrolabica stretching from fols. $75 \mathrm{rb}$ to $85 \mathrm{vb}$, which is passed over in silence in standard works such as Millàs Vallicrosa's Assaig or Borrelli's Aspects of the Astrolabe. ${ }^{22}$ This section concludes with a roughly 1000-word long text headed De compositione quadrae, id est quarta parte astrolabii, which opens Si vis componere quadram prius habeas tabulam rectissime quadratam. I shall refer to it as De compositione in what follows.

As with Circuli quadram, the previously neglected De compositione starts off by describing the instrument's construction before listing the familiar steps required to read the time of the day off its parallel 'hour-lines'. Rather than specifying the number of these lines, the author gives his reader free rein in drawing them "as closely together as you like" (quanta propinquitate volueris) [1. 54]. It is interesting to note, moreover, that he envisions the use of small wax dots to mark the point on the thread where the plumb line meets the upper end of the hour-line that will represent noon at the relevant latitude [11. 71-72]. This option is also

\footnotetext{
${ }^{21}$ For a description of the manuscript, see Nothaft, Walcher of Malvern (cit. note 11), pp. 83-85. A probable terminus post quem for at least some parts of the manuscript follows from the dating clause mentioning 1126 on fol. 159rb. A terminus ad quem of c.1140 can be inferred from John of Worcester's use of two texts in this codex when writing his continuation of the chronicle of Marianus Scottus (MS Oxford, Corpus Christi College, 157, pp. 379-396). See Patrick McGurk (ed.), The Chronicle of John of Worcester, 3 vols., Vol. 3: The Annals from 1067 to 1140 with the Gloucester Interpolations and the Continuation to 1141 (Oxford: Clarendon Press, 1998), pp. 210 (n. 2), 261 (n. 33), 285 (n. 11).

${ }^{22}$ Millàs Vallicrosa, Assaig (cit. note 12); Borrelli, Aspects (cit. note 10).
} 
mentioned in Circuli quadram, which tells us to "make a point of wax on the plumb line, or the plumb line has a small 'runner', as is the custom with some of them." ${ }^{23}$ Such a runner or bead, however, is also mentioned in the construction part of De compositione, which instructs readers to afix to the plumb line's right end "a very small circle that can be moved from one end to the other, as needed" (parvulus circulus qui possit duci a fine usque ad finem prout opus fuerit) [11. 60-61]. The inclusion of this detail is clearly at odds with the recommendation of using wax dots in the following paragraph, which raises the possibility that the 'construction' and the 'use' parts were drawn from different sources.

While the 'use' part in De compositione does not differ significantly from that in Circuli quadram (or any of the other texts already mentioned), the same is not true for the much longer 'construction' part, which goes into an unmatched amount of detail concerning the instrument's design. This is true in particular for the cursor, the construction of which takes up more than half of the entire text [11. 9-49]. In reading this section, one is puzzled by the text's manner of mentioning cursors in the plural, as if different cursors were needed for different latitudes [11.9-10]. We are told that each cursor must cover as many degrees on the quadrant's limb as the Sun covers in altitude during its ascent from the winter to the summer tropic, but the added qualifier secundum mensuram climatis ad quod pertinet [11. 12-13] wrongly implies that the size of this ascent, and hence the maximum value of the solar declination, somehow differs from latitude to latitude. Some confusion between the concepts of solar altitude (which depends on latitude) and solar declination (which does not) appears to have been at work here.

\footnotetext{
${ }^{23}$ MS Göttingen, Niedersächsische Staats- und Universitätsbibliothek, philos. 42, fol. 12v: “Qua notata duc perpendiculum ad caput eiusdem linee ex altera parte versus pinnulas; et ubi eam tangit perpendiculum, tu in cera perpendiculi fac punctum vel perpendiculum, ut apud quosdam mos est, habeat cursorem parvulum."
} 
More important than these signs of confusion, however, is De compositione's method of inscribing the months of the Julian calendar on the front of the cursor. It differs very conspicuously from the simplistic method recommended in Circuli quadram, but also from the approach described in the most widely diffused treatise on the Quadrans vetus (variously ascribed to Robertus Anglicus or Johannes Anglicus). In this thirteenth-century text, the length of the segments for the Julian months is determined quite simply by the parallel segments for the zodiacal signs, which follow the approximate proportions suggested by the standard formula for the solar declination (see below): 11;30 (for Aries/Libra, Pisces/Virgo), $8 ; 30^{\circ}$ (for Taurus/Scorpio, Leo/Aquarius) and $4^{\circ}$ (for Gemini/Sagittarius and Cancer/Capricorn). ${ }^{24}$

While the codex containing De compositione leaves us in no doubt that the Worcester scribes who copied it already had access to a table for the solar declination (or obliquatio solis), ${ }^{25}$ this concept plays no overt role in our text's approach to constructing the cursor. What we find instead is a graphical method of determining the distance between its partitions, which is based entirely on the proportions of the quadrant under construction. What is remarkable about this method is the way it takes into account the fact that the growth of the solar declination $(\delta)$ as a function of longitude $(\lambda)$ is a trigonometric function in the form of a

\footnotetext{
${ }^{24}$ Quadrans vetus, c. 11-29, ed. Hahn, Medieval Mensuration (cit. note 6), pp. 23-39; Knorr, “The Latin Sources" (cit. note 6), pp. 49-50. A similar approach is taken in the Alfonsine Libro del quadrante, bk. I.3, ed. Manuel Rico y Sinobas, Libros del saber de astronomía del Rey D. Alfonso X de Castilla, 5 vols., Vol. 3 (Madrid: Aguado, 1863-1867), pp. 295-298.

${ }^{25}$ See MS Oxford, Bodleian Library, Auct. F.1.9, fols. 110v-113r (maximum declination: $23 ; 51^{\circ}$ ), and the edition of these tables (which also cover the solar and lunar equations and lunar latitude) in Heinrich Suter (ed.), Die astronomischen Tafeln des Muḥammed ibn Mūsā al-Khwārizmī in der Bearbeitung des Maslama ibn Aḥmed al-Madjrīți und der latein. Übersetzung des Athelhard von Bath (Copenhagen: Høst \& Søn, 1914), pp. $132-137$.
} 
sine wave. In modern notation: $\sin \delta=\sin \lambda \cdot \sin \varepsilon$, where $\varepsilon$ is the value for the obliquity of the ecliptic. ${ }^{26}$

The fundamental steps of De compositione's construction plan are summarized in Fig. 2 below. It shows the quadrant with sides OI and OV [11. 2-6] and a carved-out cursor lane with a width one fifth of the total width of the quadrant [11.9-10]. The text instructs us to draw a curved line EF through the middle of the cursor [11. 14-15], which is done by placing one foot of the compass at $\mathrm{O}$ and the other at the mid-point of one of the cursor's two sides $(A B$ or $C D)$. The curved line is subtended by an auxiliary line that goes straight from $\mathrm{E}$ to $\mathrm{F}$ [11. 15-16]. It will cut the line segment from $\mathrm{O}$ to the mid-point of the quadrant's limb $\mathrm{G}$ at $\mathrm{H}$. This point is used to adjust the compass for a circle with the diameter EF, which the author asks us to draw on the back of the quadrant or on some other surface [11. 16-18].

$<$ Fig. 2 here>

This auxiliary circle is depicted in Fig. 3 below. According to the text, it is defined by points AOEI and centre V. The circumference of this circle is divided into four quadrants (OA, AI, IE, and EO), each of which is divided further into 12 equally sized segments marked by points [11. 20-22]. A curved line of the same dimensions as arc EF in Fig. 2 is added such that it is subtended by diameter IVO. This is easily done by drawing the segment of a circle whose radius is equivalent to the distance between the quadrant's vertex ( $\mathrm{O}$ in Fig. 2$)$ and the middle line of the cursor [11. 22-24]. Starting from point $O$ at the right side, straight lines are drawn to connect points on the circumference of AOEI that lie opposite to each other along the axis of diameter IVO [11. 24-29]. An exception is here made for the points nearest to O and I, as the resulting chords would be too close to the circumference.

\footnotetext{
${ }^{26}$ Otto Neugebauer, A History of Ancient Mathematical Astronomy, 3 vols., Vol. 1 (Berlin: Springer, 1975), pp. $30-31$.
} 
Now, the intersections between these chords and the diameter as well as the corresponding arc IO divide both the diameter and the arc into 22 segments of unequal size. Using a pair of compasses and a ruler, these segments are subsequently transferred onto the cursor, whose middle line is equivalent to arc IO [11. 30-41]. As seen from Fig. 3, the segments are largest near the centre and became increasingly narrow as one moves towards the extremes. Basic trigonometry dictates that this increase and decrease takes a sinusoidal form. After all, the combined length of any segments from the centre of the circle toward $\mathrm{O}$, for instance to point $\mathrm{R}$ marked in Fig. 3, will depend on the cosine of the angle $\theta$ subtended by the arc from $\mathrm{O}$ to the point on the circumference that is joined to $\mathrm{R}$ by a line perpendicular to radius VO. If the length of this radius is assumed to be equivalent to the maximum solar declination (such that $\delta=\varepsilon$ ), AOEI's circumference can be taken to represent the $360^{\circ}$ of the Sun's annual path, such that points $O$ and I correspond to longitudes $(\lambda)$ of $90^{\circ}$ or $270^{\circ}$ (at which $\delta=\varepsilon$ ), whereas A and E correspond to longitudes $0^{\circ}$ or $180^{\circ}$ (at which $\delta=0^{\circ}$ ). On this interpretation, the value of the aforementioned angle ( $\theta$ in Fig. 3) is phase shifted by $90^{\circ}$, which in turn means that the cosine function determining the length of VR is really a sine function-as demanded by the task of calculating the increase in solar declination.

$<$ Fig. 3 here>

The dividends paid by this approach to partitioning the cursor may be gleaned from Figs. 4 and 5 below. The first reflects De compositione's intended allotment of segments on the cursor to months of the Julian calendar [11. 35-37, 41-49]. It may be seen that June and December are each only given a tiny segment at the cursor's edges, which is reflective of the extremely slow change in declination around the solstices. The text notifies us that the names of June and December are written vertically across the middle line, such that June's name starts below the line, in the inner half of the cursor, and ends above it, in the outer half (vice versa for December) [11. 45-48]. Fig. 6 indicates where the author would have placed the 
twelve zodiacal signs, had he intended to include them. Their placement follows straightforwardly from the definition of the cursor's mid-point as the location of the equinoxes [1.67], as also reflected in the eleventh-century drawings mentioned earlier.

<Fig. 4 here>

$<$ Fig. 5 here $>$

De compositione's clever use of an auxiliary circle and its chords as a means of approximating the change of solar declination per Julian month raises some tantalizing questions about this text's origin and underlying sources. A number of possibilities deserve to be taken into account. Probably the least attractive of these is the assumption that the method just described was invented from scratch in eleventh- or early-twelfth century Latin Europe. The relatively impoverished state of mathematical astronomy in this period and region makes such a scenario appear doubtful. That said, one might speculate that someone in Latin Europe successfully attempted to reverse-engineer the cursor on an instrument that had been introduced from Muslim Spain. From an Arabic treatise published by King in 2002, it is known that cursors had been attached to Islamic quadrants as early as the ninth or tenth century, ${ }^{27}$ even as no construction plan for a cursor seems to have survived. The possibility that De compositione is based, in one way or another, on a lost Arabic text certainly needs to be taken very seriously. As an alternative, one might propose that our Latin text reflects practical knowledge that was first transmitted orally in a cultural contact zone such as Catalonia. $^{28}$

\footnotetext{
${ }^{27}$ See the edition and translation in King, “A Vetustissimus Arabic Treatise” (cit. note 5), pp. 243-249.

${ }^{28}$ On this background, see Julio Samsó, "Cultura científica àrab i cultura científica llatina a la Catalunya altmedieval: el monestir de Ripoll i el naixement de la ciència catalana," Symposium Internacional sobre els orígens de Catalunya (segles VIII-IX), 2 vols., Vol. 1 (Barcelona: Real Academia de Buenas Letras, 1991), pp. 253-269; Julio Samsó, "La introducción de la astronomía árabe en Cataluña a fines del siglo X," in Ante el
} 
Another question one can only speculate about concerns the channels through which this construction plan for the quadrans vetustissimus may have reached the scriptorium of Worcester Priory. One possible lead is provided by the work that follows De compositione in the same manuscript: Walcher of Malvern's De lunationibus (fols. 86ra-96ra). This multifaceted treatise is well known as the text in which Walcher, the prior of Great Malvern near Worcester, described his pioneering efforts to measure the precise time of a lunar eclipse in order to construct a set of conjunction tables (which appear on fols. 91v-93v). According to Walcher's own account, he witnessed the Moon turn dark shortly before sunrise on 18 October 1092 and at once grabbed his astrolabe to determine the time, using the Moon's altitude at mid-eclipse as the input for his computation. ${ }^{29}$ The full text of his report invalidates an argument put forward by Emmanuel Poulle, who denied that Walcher could have used an astrolabe for anything more than the conversion of temporal into equinoctial horus and instead suggested that his actual time-measuring device was a nocturlabe. ${ }^{30}$ It is still conceivable, however, that the initial altitude measurement was carried out with a

milenario del reinado de Sancho el Mayor: un rey Navarro para España y Europa; XXX Semana de Estudios Medievales, Estella, 14 a 18 de julio de 2003 (Pamplona: Gobierno de Navarra, Departamento de Cultura y Turismo, Institución Príncipe de Viana, [2004]), pp. 301-317; Samsó, "Els inicis de la introducció de la ciència àrab a Europa a través de Catalunya," in La ciència en la història dels Països Catalans, edited by Joan Vernet and Ramon Parés, 3 vols., Vol. 1 (Valencia: Institut d'Estudis Catalans, 2004-2009), pp. 115-159; David Juste, Les Alchandreana primitifs: étude sur les plus anciens traités astrologiques latins d'origine arabe ( $X^{e}$ siècle) (Leiden: Brill, 2007), pp. 1-6, 219-257.

${ }^{29}$ Walcher of Malvern, De lunationibus, 4.1, ed. and trans. Nothaft, Walcher of Malvern (cit. note 18), pp. 114117.

${ }^{30}$ See Emmanuel Poulle, "Walcher de Malvern et son astrolabe (1092)," Revista da Universidade de Coimbra, 1980, 28:47-54, and the criticism of this position in Nothaft, Walcher of Malvern (cit. note 18), pp. 33-34. 
separate instrument, which, for whatever reason, was left out of Walcher's report. ${ }^{31}$ The obvious candidate for such an instrument would be the quadrant.

No direct evidence of Walcher's familiarity with the quadrant exists. It is worth noting, however, that his De lunationibus comes without any ascription in the manuscript from Worcester Cathedral Priory. Instead, his authorship has to be inferred from a crossreference contained in the text that immediately follows, which summarizes the astronomical doctrines Walcher had learned from the converted Jew Petrus Alfonsi in $c .1120 .{ }^{32}$ Conceivably, the sequence of texts by Walcher in the Worcester manuscript comprises more than just the two commonly ascribed in him, meaning that he was also involved in writing, redacting, or transmitting De compositione. The style and vocabulary in the latter work are many ways reminiscent of the third chapter of De lunationibus, in which Walcher describes the construction of an hour-line diagram inspired by his astrolabe. Given the technical nature of these two texts, one certainly should not overrate the recurrence of certain words and phrases (e.g., fac or facias circulum [1. 17]; pone pedem circini [1. 32]; alter [pes] attingat [11. 17, 22-23, 32]; lineam ducat curvatam [1. 24]; ubi tangit ... lineam [11. 25-26]. ${ }^{33}$ Still, it may be more than a pure coincidence that the auxiliary circle in De compositione [11. 20-21] employs exactly the same set of Latin vowels to designate the centre and four quadrants (A top, O right, E bottom, I left, $\mathrm{V}$ centre) as does the circle containing the diagram in $D e$ lunationibus. $^{34}$

\footnotetext{
31 This seems to be the interpretation suggested in Borrelli, Aspects (cit. note 10), pp. 162-163.

32 This text is known as De Dracone. See the introduction, edition, translation, and commentary in Nothaft, Walcher of Malvern (cit. note 18), pp. 46-55, 194-217, 271-297.

${ }^{33}$ Walcher of Malvern, De lunationibus, 3.3, ibid., pp. 104-109.

${ }^{34}$ Walcher of Malvern, De lunationibus, 3.2-3, ibid., pp. 102-105.
} 
If De compositione became available in Worcester through the mediation of Walcher of Malvern, this could also explain more generally how the quadrans vetustissimus first came to England. According to an inscription on his stone coffin lid, Walcher was born in Lotharingia, ${ }^{35}$ a region where knowledge of the astrolabe was disseminated much earlier than in England. As a matter of fact, it is Walcher's account of the eclipse of 1092 that provides us with the earliest solid attestation of an astrolabe being available anywhere north of the English Channel. From the aforementioned hour-line diagram, but also from the accuracy of Walcher's time-measurement, it is clear that his astrolabe was equipped with a horizon plate adequate to the latitude of Great Malvern, ${ }^{36}$ but this tells us nothing about the origin of the instrument itself. Given the lack of signs that astrolabes were used in England before Walcher's arrival, one is tempted to conclude that he brought his own specimen over from the continent. Perhaps the universal horary quadrant was part of the same luggage.

\footnotetext{
${ }^{35}$ Ibid., p. 10.

${ }^{36}$ Ibid., pp. 36, 111, 233-235, 237-238, 243-244.
} 


\section{Appendix: Edition of De compositione quadrae}

What follows is the text as found in MS Oxford, Bodleian Library, Auct. F.1.9, fols. 85rb-vb. Rubricated words appear in SMALL CAPS.

\section{DE COMPOSITIONE QUADRAE, ID EST QUARTA PARTE ASTROLABII}

$\mathrm{Si}$ vis componere quadram prius habeas tabulam rectissime quadratam ante te, in cuius angulo superiori qui respicit ad sinistram ponatur o littera; in inferiori ad sinistram pone I; in superiori ad dexteram V. Duc ergo lineam unam ab o ad V et alteram ab o ad I, que in medio ipsius $\mathrm{O}$ angulariter conveniant in modum crucis. In quo loco posito uno circini pede alter ponatur in $\mathrm{V}$ et ducatur usque ad I, faciens $\mathrm{IIII}^{\mathrm{AM}}$ partem circuli; et auferatur quicquid extra remanet. Hinc ab I ad v ponantur XC gradus cum quinque partibus, sicut in $\mathrm{IIII}^{\mathrm{TA}}$ parte ASTROLABII.

Infra illos facias alium circulum relinquens latitudinem unius quinquepartiti, que cavanda est ut diversi cursores possint imponi secundum diversitates climatum. Qui cursores debent formari eadem compositione circini qua est ipsa cavatura, qui possint imponi a parte I et currere usque ad v. Et uniuscuiusque longitudo tanta debet <esse> ut secundum mensuram climatis ad quod pertinet tot gradus exterioris circuli optineat quot habet sol in ascensione sua ab hiemali circulo usque ad estivum. Et ducatur per medium eius linea ab uno capite usque ad aliud circumductione circini. Et quia curvata est linea ista, ducatur alia linea recta, ab uno ipsius capite usque ad aliud; et componatur circinus ita ut [85va] altero pede in medio huius recte linee stante, alter utrunque caput attingat; et non mutato circino fac circulum in altera superficie eiusdem vel, si vis, in alia tabula. Iste circulus erit magister ad positionem mensium in cursore et eorum divisionem. dexteram $\mathrm{O}$, in centro V. Pars autem queque de $\mathrm{IIII}^{\mathrm{OR}}$ dividatur in tria, queque iterum in duo, 
tertio unaqueque in duo. Compone igitur circinum in quadra ut uno pede stante in o alter attingat mediam cursoris positi in cavatura. Hinc redeas ad circulum quem composuisti et sic in tali in loco pone alterum pedem circini, ut alter lineam ducat curvatam ab I ad o. Deinde a puncto secundo ab o ex parte una usque ad $\mathrm{II}^{\mathrm{UM} 1}$ ex parte altera ducatur linea et ubi tangit curvatam lineam novissime ductam ab I ad o, fac signum. Duc iterum lineam a III $^{\mathrm{O}}$ puncto ex una parte o usque ad $\mathrm{III}^{\mathrm{UM}}$ ex altera parte et nota iterum lineam ubi tangitur. Et tali modo pertranseas per omnes oppositos punctos signando semper lineam usque ad secundos punctos $^{2}$ ex utraque parte I.

Ecce habes in divisione huius linee $\mathrm{XX}^{\mathrm{TI}} \mathrm{II}^{\mathrm{AS}}$ partes. Et quia linea ista coequalis est medie linee cursoris, divide et illam cursoris videlicet lineam equaliter in duo. Hinc redi ad aliam lineam que in $\mathrm{XX}^{\mathrm{TI}} \mathrm{II}^{\mathrm{O}}$ divisa est et pone pedem circini in medio ut alter pes attingat extremas notas, quarum una proxima est o littere et altera I. Hinc redi ad lineam cursoris et circini sic temperati uno pede posito in medio ut alter in duobus capitibus tangat lineam, fac duas divisiones cursoris descendente regula ${ }^{3}$ ab o. Et reliquisti in utroque capite unum parvum spatiolum: in superiori, quod respicit ad v, ubi ponendus est Iunius, quia spatium eius est; in inferiori, quod respicit ad I, December.

Hinc redeundum est ad lineam iam divisam et, sicut per notas proximas o et I fecisti has duas divisiones, sic per $\mathrm{II}^{\mathrm{AS}}$ ex utraque parte huius linee facias in linea cursoris similiter ex utraque parte divisiones secundas, et per duas tertias et sic deinceps usque dum venias ad duas notas ex utraque parte proximas medietati. Quattuor itaque partes que sunt sub mense Iunio pertinent ad Maium et Iulium; alie $\mathrm{IIII}^{\mathrm{OR}}$ que sequuntur, Aprilis et Augusti; $\mathrm{IIII}^{\mathrm{OR}}$ sequentes, Martii et Septembris; iterum alie IIII ${ }^{\mathrm{OR}}$, Februarii et Octobri. Restant adhuc $\mathrm{IIII}^{\mathrm{OR}}$

\footnotetext{
$\left.{ }^{1} \mathrm{II}^{\mathrm{um}}\right] \mathrm{II}^{\mathrm{am}}$

2 signando semper ... secundos punctos] gem.

${ }^{3}$ regula] regula s.l. p.c.; linea a.c.
} 
que sunt Ianuarii et Novembri. Et quia media [85vb] linea dividit ipsum cursorem in duos quasi semicyclos, scribatur Iunius in superiori capite per transversum, ut pars nominis prima sit in interiori circulo et pars in exteriori. Deinde sequatur Iulius occupans $\mathrm{IIII}^{\mathrm{OR} 4}$ partes, Augustus alias IIII ${ }^{\mathrm{OR}},{ }^{5}$ September IIII ${ }^{\mathrm{OR}},{ }^{6}$ October IIII ${ }^{\mathrm{OR}},{ }^{7}$ November IIII ${ }^{\mathrm{OR}}$. December in capite scribatur inceptus in exteriori. Quinque menses qui restant scribantur in interiori circulo eodem ordine quo $\mathrm{V}^{\mathrm{E}}$ in exteriori positi sunt, sed incipiatur scribi versa quadra a parte $\mathrm{I}$. Intra hos circulos componantur $\mathrm{II}^{\mathrm{O}}$ alii circuli ad horarum positionem et dividantur in VI partes unicuique attributis tribus decanis. In interiori prima parte circuli a parte I ponatur prima, hinc II, III, IIII, V, VI. Iterum descendendo per exteriorem primum ponatur VII, VIII, IX, X, XI, XII. De superiori latere inter O et V ducantur linee deorsum usque ad circulum horarum quanta propinquitate volueris et occupent quicquid spatii est inter circulos horarum. Iam perpendiculum apponatur in loco ubi est o. Relinquatur undique tantum de tabula ut foramen parvulum fieri possit, in cuius medio conveniant due collaterales linee ab I et $a b \mathrm{~V}$ venientes. Et ponatur in eo clavus de quo perpendiculum pendeat. Foramen in eius superiori capite ita fiat ut linea dextri lateris per medium eius dirigi possit de relicto ex ligno a parte dextera perpendiculi quod sufficiat. Alterum caput grossissimum excedat tabulam totumque in dextera parte fiat. Aliter enim recte non penderet cum foramen non in medio, sed in latere dextro sit positum. In eius latere dextro ponatur parvulus circulus qui possit duci a fine usque ad finem prout opus fuerit. In superiori fronte quadre due pinne remote abinvicem infingantur, in quibus fiant duo parva foramina ad radium solis recipiendum.

\footnotetext{
$\left.{ }^{4} \mathrm{IIII}^{\mathrm{OR}}\right] \mathrm{IIII}^{\mathrm{A}}$

$\left.{ }^{5} \mathrm{IIII}^{\mathrm{OR}}\right] \mathrm{IIII}^{\mathrm{A}}$

$\left.{ }^{6} \mathrm{IIIII}^{\mathrm{OR}}\right] \mathrm{IIII}^{\mathrm{A}}$

$\left.{ }^{7} \mathrm{IIII}^{\mathrm{OR}}\right] \mathrm{IIII}^{\mathrm{A}}$
} 
Si quadram componere scis neque ad quid componatur, operari non tibi scivisti, sed

65 aliis. Ut autem et tibi scias: cum alicuius diei presentem horam invenire vis, primum te scire necesse est latitudinem climatis in quo es et habere in quadra cursorem eidem congruum latitudini. Tunc cursoris medietas, que utrunque habet equinoctium, sic collocanda est ut de XC gradibus numerus designans latitudinem ${ }^{8}$ climatis ad dexteram habeatur et quod reliquum est ad sinistram. Tunc pone perpendiculum super presentem mensem et super presentem diem et considera que linea in inferiori capite contingat ipsum perpendiculum. Et elevato perpendiculo usque ad eiusdem superius linee caput, ubi tangitur ab ea, fac punctum incera omnium horarum diei eiusdem indicem. Inquirens itaque horam coapta quadram radio solis per utrunque foramen duarum pinnarum transeunti et vide cuius linee extremitati perpendiculum immineat; et move perpendiculum ipsum quousque punctus quem prius incera feceras ipsam lineam attingat, quo in loco quietum iacens in inferiori parte sui designat horam presentem. Amen.

\footnotetext{
${ }^{8}$ latitudinem] p.c. in mg.; a.c. altro(?) lac.
} 


\section{Figure captions}

Fig. 1: Paris, Bibliothèque nationale de France, lat. 7412, fol. 16r

80 Fig. 2: Construction of the quadrant and auxiliary circle in De compositione quadrae

Fig. 3: Construction of the cursor in De compositione quadrae

Fig. 4: Placement of months on the cursor

Fig. 5: Placement of zodiacal signs on the cursor 